\title{
Spatial pattern analysis and identification type of open green space in Yogyakarta city
}

\author{
Muhammad Dimyati ${ }^{1,2}$, Akhmad Fauzy ${ }^{3}$, and Anggara Setyabawana Putra ${ }^{1, *}$ \\ ${ }^{1}$ Directorate General of Research and Development Strengthening, Ministry of Research, Technology and Higher Education, Building \\ 2, Assessment and Application of Technology Agency (BPPT), Flor 19-20, MH Thamrin Street No. 8, Jakarta 10340, Indonesia \\ ${ }^{2}$ University of Indonesia, Department of Geology, Faculty of Mathematics and Natural Sciences, Pondok Cina, Beji, Pd. Cina, Beji, \\ Depok, West Java 16424, Indonesia \\ ${ }^{3}$ Islamic University of Indonesia, Department of Statistics, Faculty of Mathematics and Natural Sciences, Kaliurang Street KM 14.5, \\ Sleman, Yogyakarta 55584, Indonesia
}

\begin{abstract}
Open green Space is a spatial plan model aiming to maintain the quality of the environment. Nowadays, the number and distribution of Open green Space have decreased, particularly in urban areas. Such decline is due to many reasons, one of which is land conversion caused by social activities. This research aimed to analyse the distribution pattern and identify the type of Open green Space in Yogyakarta City. The method in this study using moran's I Index approach, GIS and direct field review. The results showed that the Open green Space was clustered with Moran's Index of 0,074594. Validation with field check indicated that there was an absence of even, thorough, and most recent Open green Space identification. Visual detection using high-resolution satellite images and aerial photos affirmed that many open green spaces had not been inventoried, justifying the need for data update in Yogyakarta City. The identification process resulted in different types of Open green Space, but the most widely distributed ones in Yogyakarta City were in the forms of Private yard, Office park, Green belt, and City Parks.
\end{abstract}

\section{Introduction}

Regional development is an effort to maintain and improve people's welfare. Its principle is expected to take into account some vital elements such as ecology [1-3] culture [4,5] energy [6-9] natural resources [10] and community participation [11-13]. The integration of these elements creates sustainable regional development. Urban area is a space that experiences a very rapid development, which most of the time results in unbalanced urban growth [14]. For a sustainable urban growth, the development has to be planned with an accurate target according to the characteristics of the region.

The characteristics of a region significantly determine the implemented regional development planning policy. A thorough comprehension of these properties leads to maximum and efficient extraction and utilization of local potentials and resources. Regional development planning has to consider environmental condition and quality $[15,16]$ One step to maintain the environmental quality in the development is by opening access to the arrangement of open green space [17]. Open green spaces in urban areas are recognized as valuable for the benefits they provide, such as biodiversity conservation and spaces for people to relax [18]

In addition to maintaining the quality of the environment, open green space can also be used as a place of recreation $[19,20]$. It is also applicable as disaster mitigation measures [21] for air pollution disasters [22-24], floods [25,26], and drought [27] In term of air pollution, open green space serves as the design of an area used for green plants, which filter solid particles that can cause air pollution. It can be functioned to maintain groundwater availability to avoid any potentials of drought disaster. Furthermore, it can also stabilize the temperature in a region [28].

In general, sustainable development can take place by considering some of the main pillars namely, social, environmental and economic. The interaction of the three pillars can have positive and negative effects in an urban area (Figure 1.).

\footnotetext{
* Corresponding author: setyabawana@gmail.com
} 


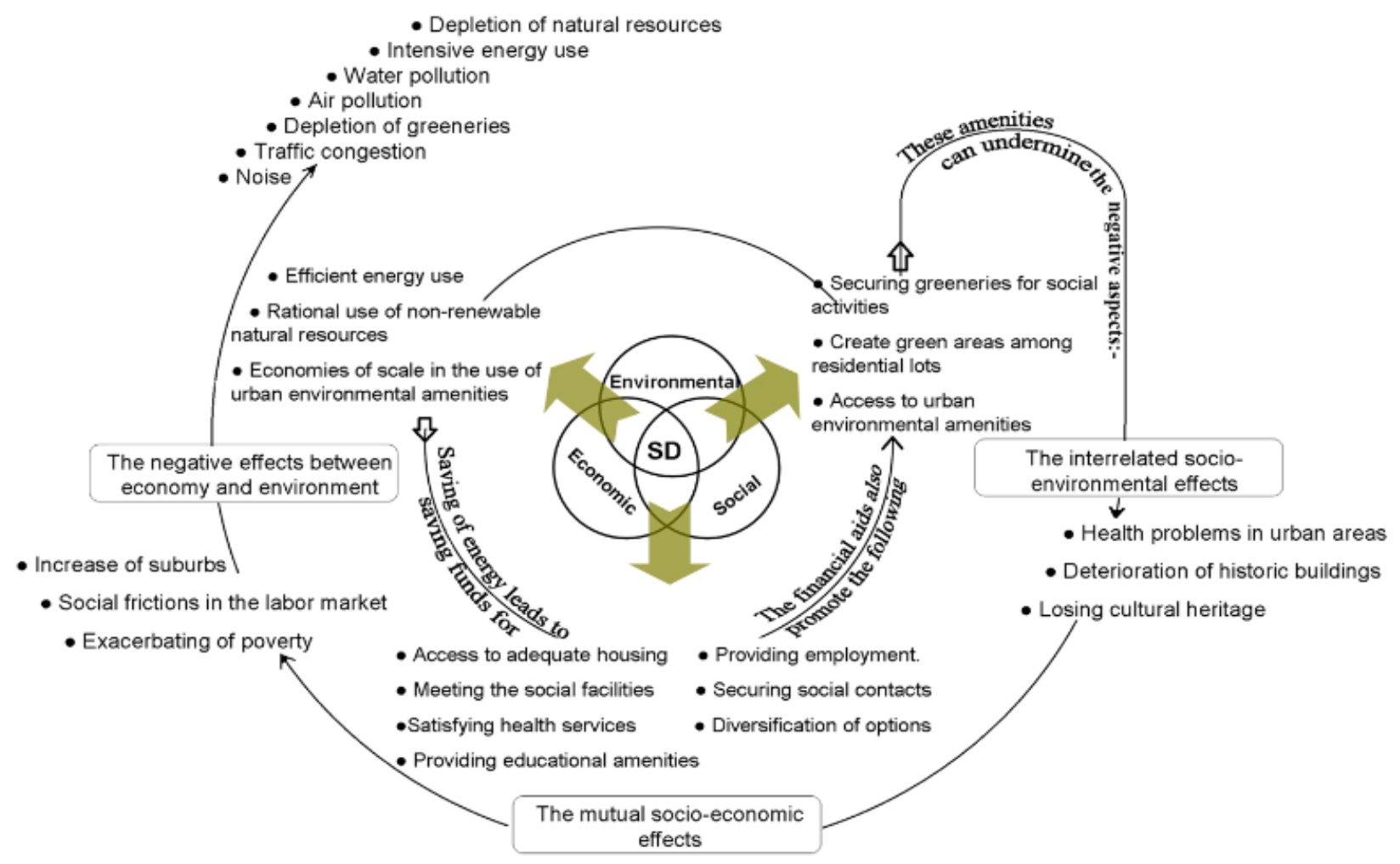

Fig. 1. The positive and negative external effects in the interaction between different environments in a city [29].

Open green space in urban areas is the primary requirement for ecological balance and, thereby, human welfare [30]. Purpose of this research, is analyzed the distribution pattern and identified the type of open green space in Yogyakarta City, i.e., one of the urban areas with rapid development in the Special Region of Yogyakarta

\section{Method}

This research used both primary and secondary data. The primary data were the results of field survey that identified the types of open green space in the specified sampling points. These types represent the condition of the latest open green space model in the study area. Meanwhile, the secondary data consisted of spatial data, which can be observed in Table 1.

Table 1. Data Requirement.

\begin{tabular}{|l|l|l|}
\hline \multicolumn{1}{|c|}{ Drimary } & \multicolumn{2}{|c|}{ Secondary } \\
\hline $\begin{array}{l}\text { Documentation of } \\
\text { condition the latest } \\
\text { open green space }\end{array}$ & $\begin{array}{l}\text { Spatial } \\
\text { Data }\end{array}$ & $\begin{array}{l}\text { High-resolution } \\
\text { satellite images }\end{array}$ \\
\hline & & $\begin{array}{l}\text { Maps of administrative } \\
\text { boundaries the villages }\end{array}$ \\
$\begin{array}{l}\text { UAV-derived } \\
\text { photos }\end{array}$ & $\begin{array}{l}\text { The distribution points } \\
\text { of open green space }\end{array}$ \\
\hline
\end{tabular}

Land use conversion changes the conditions of an area, including the open green space. The management and arrangement of open green space are adjusted to the state of the ecosystem in the region. Therefore, the types of open green space differ between areas. To identify the types of open green space available in the study area, this research conducted an inventory by documenting objects of open green space based on the predefined sampling points. It also used Unmanned Aerial Vehicle (UAV) to produce the aerial photos of the study area. Since UAV-derived images have a high spatial resolution [31-35], they can describe the condition of an area in detail.

High-resolution satellite imagery is one of the advances in remote sensing technology. Satellite images depicting the conditions of the Earth's surface used to have a small spatial resolution, but now they provide spatial data with high resolution [36-38] for instance, the photos captured by UAVs. To identify the distribution pattern of the open green space, this research used the administrative boundaries of the villages in Yogyakarta City. Another supporting data was the location of the open green space.

In general, there were two analyses in this research, namely direct identification of open green space model and distribution pattern analysis of the open green space using the Moran's Index. The direct identification used visual detection on the documentation results and UAVderived photos during the field survey. Meanwhile, the distribution pattern was analyzed with mapping software. The analysis process is presented in detail in the flowchart in Figure 2. 


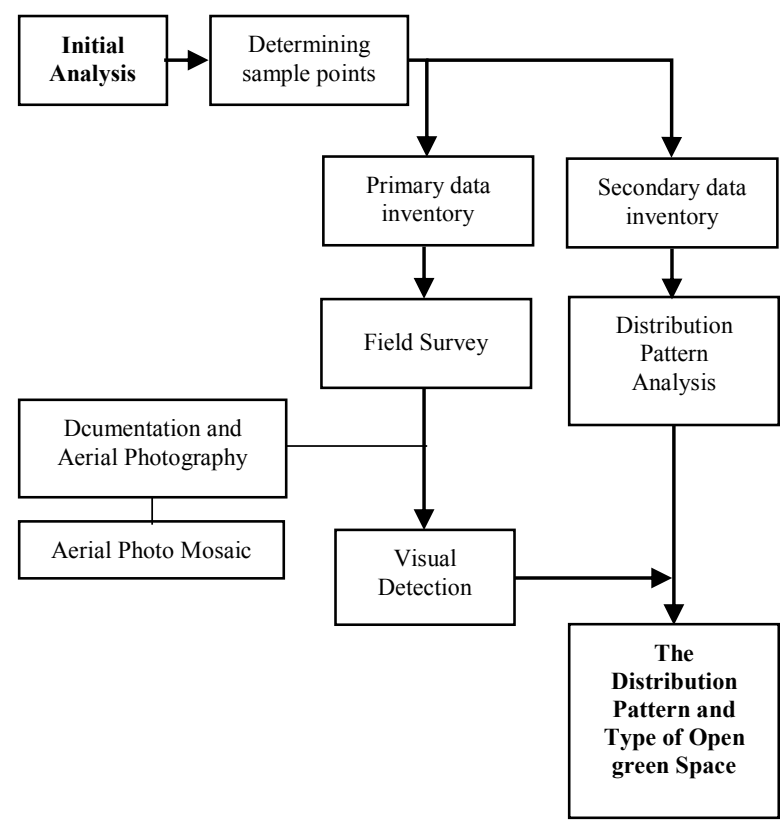

Fig. 2. Research Flowchart.

The distribution pattern of open green space was identified with the Moran's Index, which is presented mathematically in Equation 1 and 2. This index determines the relationship pattern between the observable values by considering spatial elements (Spatial Autocorrelation).

Equation 1. Unstandardized Spatial Weights Matrix:

$$
\begin{aligned}
& I=\frac{n \sum_{i=1}^{n} \sum_{j=1}^{n} w_{i j}^{*}\left(x_{j}-\bar{x}\right)\left(x_{j}-\bar{x}\right)}{S_{0} \sum_{i=1}^{n}\left(x_{i}-\bar{x}\right)} \\
& S_{0}=\sum_{i=1}^{n} \sum_{i=1}^{n} w_{i j}^{*}
\end{aligned}
$$

$w_{i j}^{*}$ : elements in unstandardized weight between location $i$ and $j$

Standardized Spatial Weights Matrix :

$$
I=\frac{n \sum_{i=1}^{n} \sum_{j=1}^{n} w_{i j}\left(x_{j}-\bar{x}\right)\left(x_{j}-\bar{x}\right)}{\sum_{i=1}^{n}\left(x_{i}-\bar{x}\right)^{2}}
$$

\section{Results and Discussion}

\subsection{Open green Space Model in Yogyakarta City}

Yogyakarta City is the center of development and economic activity in the Special Region of Yogyakarta. Infrastructure is the aspect with the most rapid growth in this city as it primarily aims to meet the persistently increasing public needs and economic activities. Such growth is characterized by the rising number of shopping centers and hotels. The direction of regional development is strongly related to the local spatial planning model, as well as the organization of open green space. This relationship leads to the diverse models of open green space in Yogyakarta City.

The sampling sites for identifying the open green space model in the study area is depicted in Figure 3. These sites were determined using purposive sampling technique.

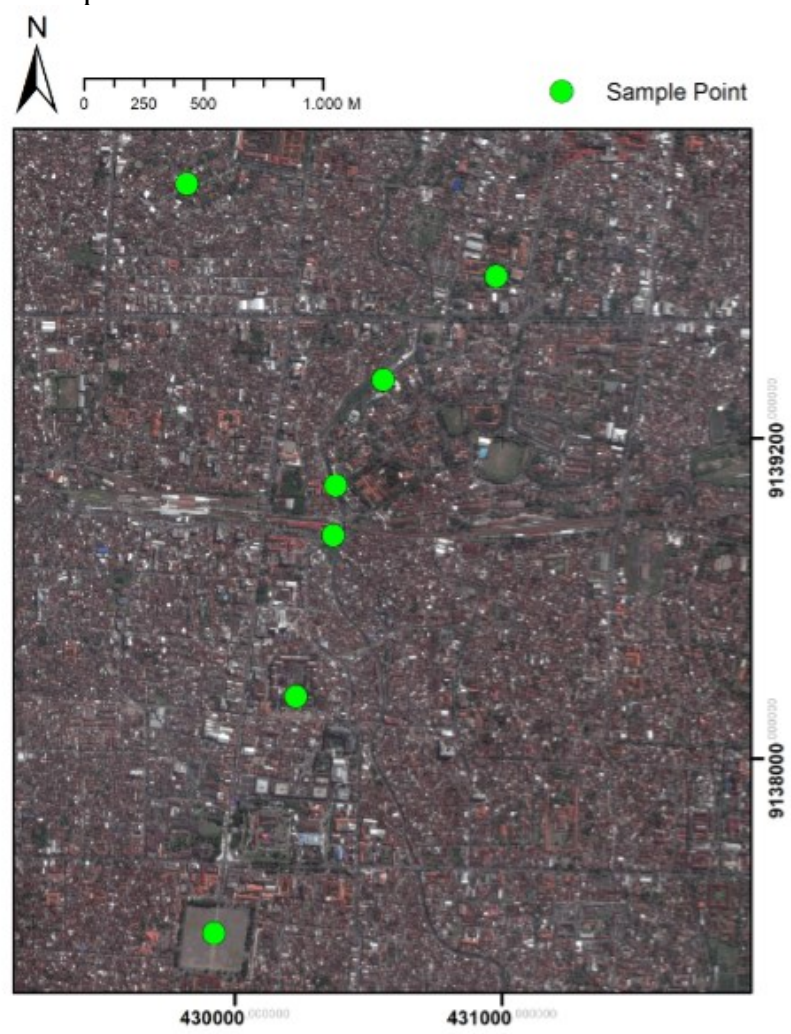

Fig. 3. Sample point.

Based on the results of direct identification in the field and visual detection, the open green space model in Yogyakarta City is summarized in Table 2.

I : Moran's Index

$\mathrm{n} \quad$ : the total number of locations

$x_{i} \quad$ : vathe lue in $i$-th location

$x_{j} \quad$ : vathe lue in $j$-th location

$\bar{x} \quad$ : average variable or value

$w_{i j}$ : elements in standardized weight between location $i$ and $j$ 
Table 2. Data Requirement.

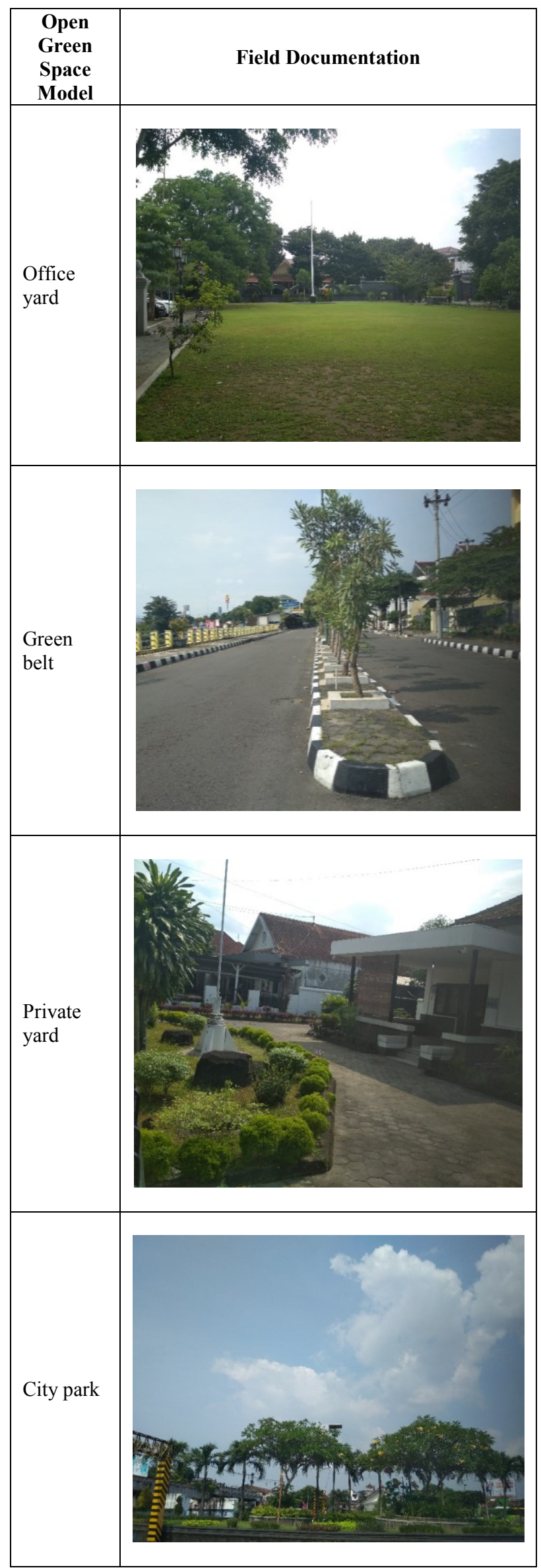

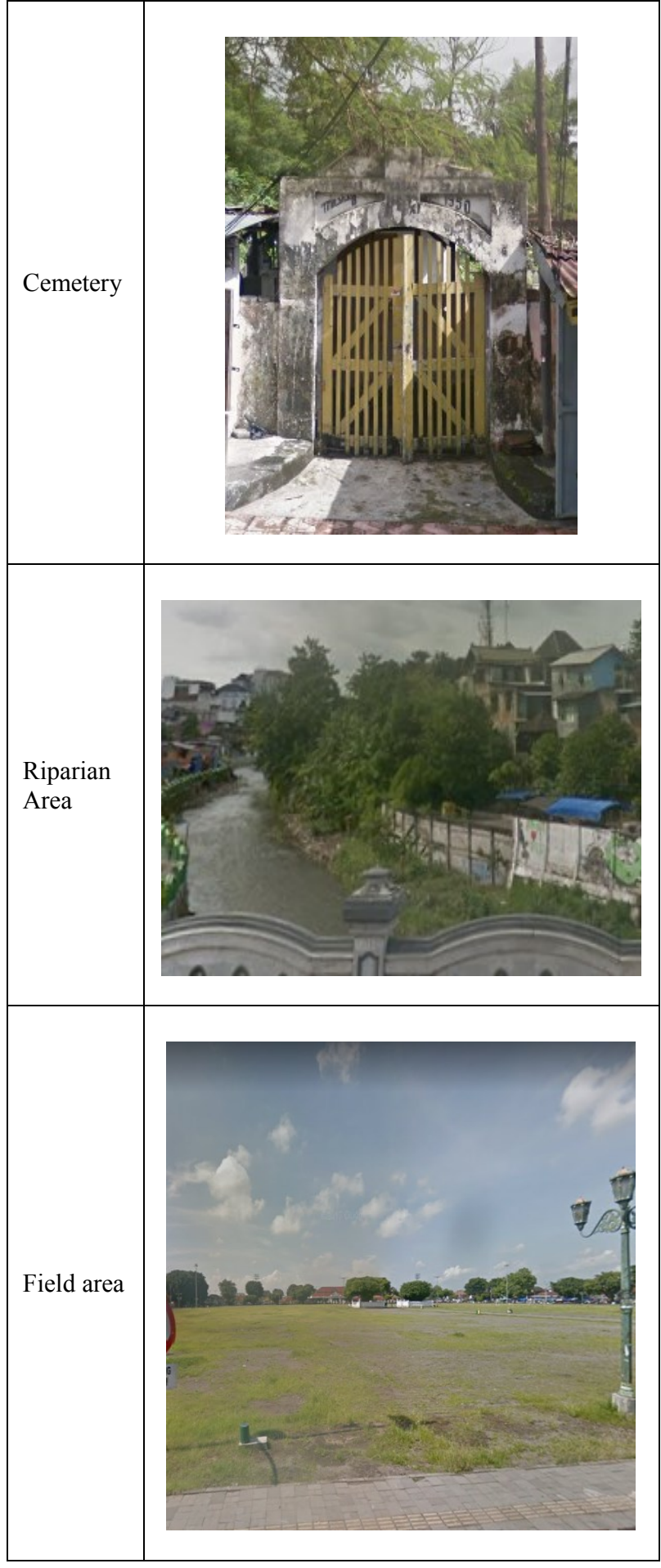

\subsection{The Distribution Pattern of Open green Space in Yogyakarta City}

The method used to identify the distribution pattern of the Open green Space in Yogyakarta City was the Moran's Index. This index has been applied in various software. The data source used in the identification of the distribution pattern was the administrative boundaries of the villages in the city and the location of the Open green Space. The analysis results are presented in Figure 4. 


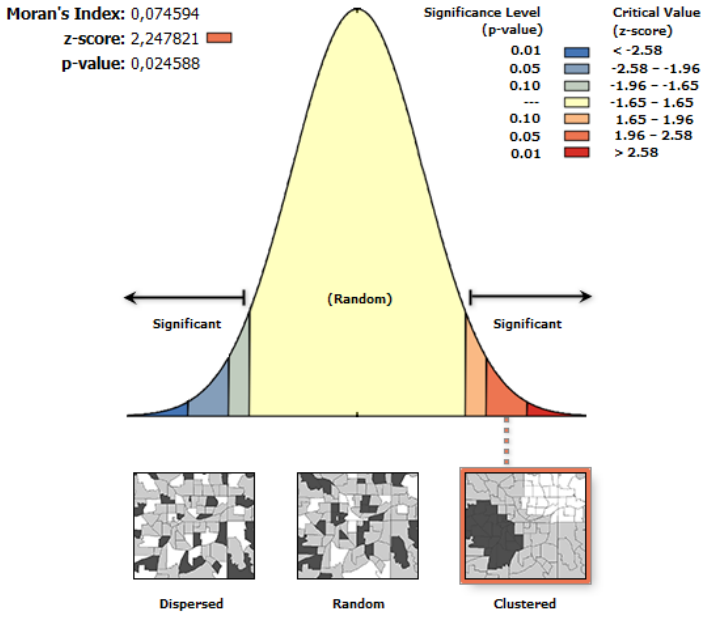

Fig. 4. Moran's Index.

From this diagram can be translated, pattern of open green space in Yogyakarta with Moran Index value 0,074594, Zscore 2,247821, p-value 0,024588 is Cluster. Because the process of inventory of open green spaces is still done in macro (general) has not done in detail. Such conditions cause the interpretation of the green space in the city of Yogyakarta is not evenly distributed, whereas the conditions in the field, there are various kinds of green space that may not have been inventory. Therefore, another method is needed for the inventory of open green space. One of them is use spatial data (spatial based).

\subsection{Spatial-based Open green Space Inventory}

Variety and types of existing data can be utilized for various purposes. One of them is spatial data that can be utilized for inventory of open green spaces. In this study, the application of spatial data utilization for open green space inventory is by using aerial photography data from Unmanned Aerial Vehicle (UAV). UAV is used copter type (quadcopter).

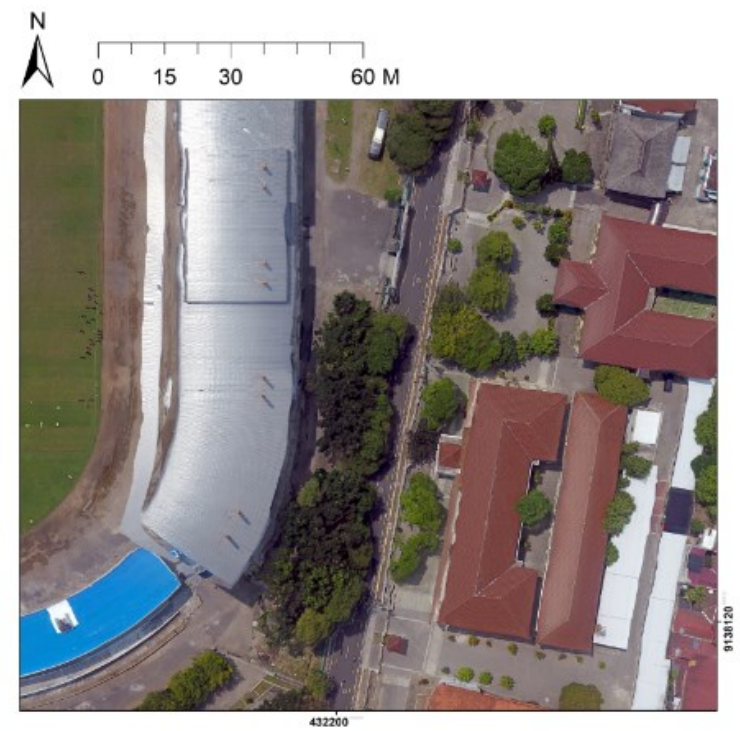

Fig. 5. Spatial data from UAV.
The aerial photograph was taken at a sample location with a height of $350 \mathrm{ft}$, obtained 25 vertical photographs. Then in the next process is mosaic aerial photos. Mosaic photo results, can be observed in Figure 5. The result of the aerial photo mosaic process was obtained have a high spatial resolution level $(4.23 \mathrm{~cm})$. The data can be used for large-scale mapping. Further testing of accuracy by comparing laboratory accuracy to the field shows, the accuracy rate up to $92 \%$.

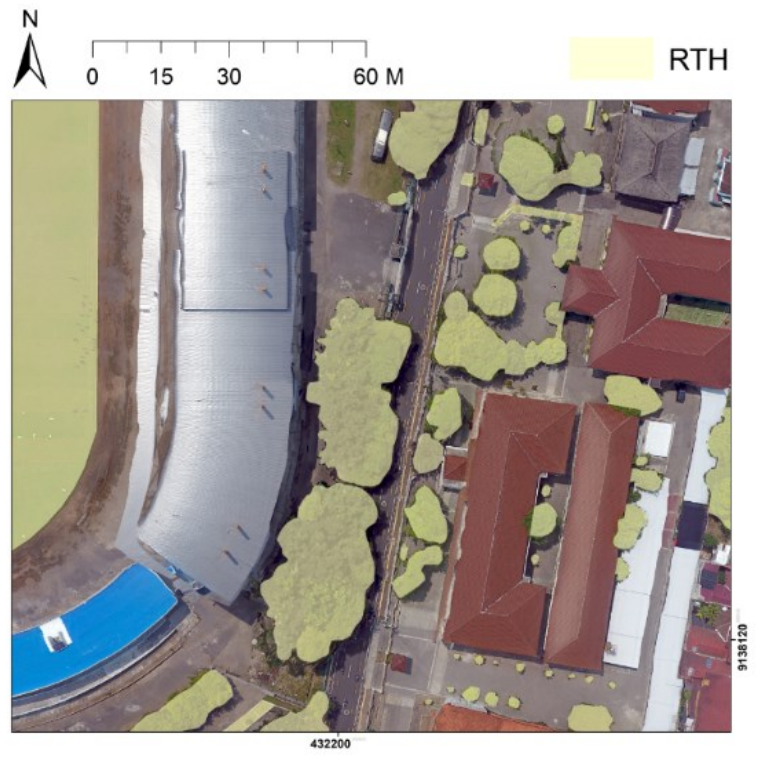

Fig. 6. Identification RTH with spatial data from UAV.

Inventory and identification of open green space based, spatial data can be applied with Landsat imagery data equipped with certain channels, but the resolution level of Landsat image data is still very small that is $30 \mathrm{M}$ and $15 \mathrm{M}$ in sharpening process. Using the aerial photograph data with spatial resolution and high accuracy inventory and identification process will get accurate RTH data.

Identification of open green spaces and this distribution needs to be done, to support sustainable development goal. Benefits of open green space can be observed in Table 3 [39].

Table 3. Environmental benefits of urban green space.

\begin{tabular}{|l|l|l|l|}
\hline Category & $\begin{array}{c}\text { Sustainable } \\
\text { Development } \\
\text { Goal }\end{array}$ & $\begin{array}{c}\text { Major } \\
\text { Issue }\end{array}$ & \multicolumn{1}{c|}{ Risk } \\
\hline \multirow{2}{*}{$\begin{array}{l}\text { Urban } \\
\text { Environm } \\
\text { ent }\end{array}$} & \multirow{2}{*}{$\begin{array}{l}\text { Energy and } \\
\text { health security }\end{array}$} & Thermal & $\begin{array}{l}\text { Heat wave, } \\
\text { UHI }\end{array}$ \\
\cline { 3 - 4 } & & Air & $\begin{array}{l}\text { Pollution, } \\
\text { Carbon } \\
\text { Sequestrati } \\
\text { on }\end{array}$ \\
\cline { 3 - 4 } & & & $\begin{array}{l}\text { Increased } \\
\text { energy use }\end{array}$ \\
\cline { 3 - 4 } & & $\begin{array}{l}\text { Strong } \\
\text { wind, and } \\
\text { Pedestratio }\end{array}$ \\
& & Wind & $\begin{array}{l}\text { n } \\
\text { discomfort } \\
\text { level }\end{array}$ \\
\hline Urban & Water Security & Natural & Water \\
\hline
\end{tabular}




\begin{tabular}{|c|c|c|c|}
\hline \multirow[t]{3}{*}{ Water } & & treatment & quality \\
\hline & & $\begin{array}{l}\text { Ground } \\
\text { recharge }\end{array}$ & $\begin{array}{l}\text { Drying } \\
\text { aquifer }\end{array}$ \\
\hline & & $\begin{array}{l}\text { Strom } \\
\text { water } \\
\text { drainage }\end{array}$ & $\begin{array}{l}\text { Urban } \\
\text { flood, and } \\
\text { Drought }\end{array}$ \\
\hline \multirow{2}{*}{$\begin{array}{c}\text { Urban } \\
\text { Agriculture }\end{array}$} & \multirow{2}{*}{ Food Security } & $\begin{array}{l}\text { Soil } \\
\text { Protection }\end{array}$ & $\begin{array}{l}\text { Soil } \\
\text { stabilisation } \\
\text { Permeabilit } \\
\text { y }\end{array}$ \\
\hline & & $\begin{array}{l}\text { Nutrient } \\
\text { cycle }\end{array}$ & $\begin{array}{l}\text { Waste } \\
\text { managemen } \\
\text { t, and } \\
\text { nutrient } \\
\text { cycling }\end{array}$ \\
\hline $\begin{array}{l}\text { Urban } \\
\text { Biodiversi } \\
\text { ty }\end{array}$ & $\begin{array}{l}\text { Habitat } \\
\text { security }\end{array}$ & $\begin{array}{l}\text { Bio- } \\
\text { diversity }\end{array}$ & $\begin{array}{l}\text { Decreasing } \\
\text { species } \\
\text { diversity } \\
\text { and habitat } \\
\text { corridors }\end{array}$ \\
\hline
\end{tabular}

\section{Conclusions}

Yogyakarta urban area designed with a variety element, whether social, cultural and environmental. Infrastructure development needs to get attention from government and all society. Sustainable development should be prioritized by promoting environmental balance. One step to preserve the environment is to create open green spaces.

Based on the results of the analysis using moran's index, the pattern of open green space in Yogyakarta is still clustered, indicating that open green space has not spread evenly, and just attention to the aesthetic elements only. In some central locations of community activities, it is necessary to build open green space so that environmental balance can be maintained. The location data of open green space area in Yogyakarta city also need to be updated. The process of updating data and inventory of open green spaces, can utilize by spatial data of aerial photography from Unmanned Aerial Vehicle (UAV) because it has a high degree of resolution and accuracy.

Authors would like to thank the Indonesian Ministry of Research, Technology, and Higher Education for supporting this research. Authors would also like to thank colleagues that have been helpful during the study.

\section{References}

1. Pandit, A., Minn, E. A., Li, F., Brown, H., Jeong, H., James, J. A. C., Newel, J. P., Weissburg, M., Chang, M. E., Xu, M., Yang, P., Wang, R., Thomas, V. M., Yu, X., Lu, Z., Crittenden, J. C. Infrastructure ecology: an evolving paradigm for sustainable urban development. Journal of Cleaner Production 163 S19-S27 (2017)

2. Wu, J., Xiang, W. N., Zhao, J. Urban ecology in China : Historical developments and future directions. Journal of Landscape and Urban Planning 125 222-233 (2014)
3. Keena, N., Raugei, M., Etman, M. A., Ruan, D., Dyson, A. Clark's Crow : A design plugin to support emergy analysis decision making towards sustainable urban ecologies. Journal of Ecological Modelling 367 42-57 (2018)

4. Kagan, S., Hauerwaas, A., Holz, V., Wedler, P. Culture in sustainable urban development: Practices and policies for spaces of possibility and institutional innovations. Journal of City, Culture and Society XXX XXX-XXX (2017)

5. Zander, K. K., Garnett, S. T., Straton, A. Trade-offs between development, culture and conservation Willingness to pay for tropical river management among urban Australians. Journal of Environmental Management 912519 - 2528 (2010)

6. Karunathilake, H., Perera, P., Ruparathna, R., Hewage, K., Sadiq, R. Renewable energy integration into community energy systems: A case study of new urban residential development. Journal of Cleaner Production 173 292-307 (2018)

7. Mosannenzadeh, F., Bisello, A., Vaccaro, R., Alonzo, V. D., Hunter, G. W., Vettorato, D. Smart energy city development: A story told by urban planners. Journal of Cities 64 54-65 (2017)

8. Yin, Y., Mizokami, S., Aikawa, K. Compact development and energy consumption: Scenario analysis of urban structures based on behavior simulation. Applied Energy 159 449-457 (2015)

9. Moghadam, A. T., Delmastro, C., Corgnati, S. P., Lombardi, P., Urban energy planning procedure for sustainable development in the built environment: A review of available spatial approaches. Journal of Cleaner Production 165 (2017) 811-827

10. Siciliano, G. \& Urban, F. Equity-based Natural Resource Allocation for Infrastructure Development: Evidence from Large Hydropower Dams in Africa and Asia. Ecological Economics 134 130-139 (2017)

11. Wang, A., Hu, Y., Li, L., Liu, B. Group Decision Making Model of Urban Renewal Based on Sustainable Development: Public Participation Perspective. Procedia Engineering 1451509 - 1517 (2016)

12. Li, H. \& Jong, M. D. Citizen participation in China's eco-city development. Will 'new-type urbanization' generate a breakthrough in realizing it?. Journal of Cleaner Production 162 1085-1094 (2017)

13. Fors, H., Molin, J. F., Murphy, M. A., Boch, C. K. V. D. User participation in urban green spaces - For the people or the parks?. Journal of Urban Forestry \& Urban Greening 14 722-734 (2015)

14. Ayllon, S. G. 2016. Rapid development as a factor of imbalance in urban growth of cities in Latin America : A perspective based on territorial indicators. Habitat International 58 127-142 (2016)

15. Mersal, A. Sustainable Urban Futures : Environmental Planning for Sustainable Urban 
Development. Procedia Environmental Sciences 34 $49-61$ (2016)

16. Panagopoulos, T., Duque, J. A. G., Dan, M. B. Urban planning with respect to environmental quality and human well-being. Environmental Pollution 208 137-144 (2016)

17. Wüstemann, H., Kalisch, D., Kolbe, J. Access to urban green space and environmental inequalities in Germany. Journal of Landscape and Urban Planning 164 124-131 (2017)

18. Lee, B. K., Sohn, S. Y., Yang, S. Design guidelines for the Dashilar, Beijing Open Green Space Redevelopment Project. Journal of Urban Forestry \& Urban Greening 13 385-396 (2014)

19. Chan, C. S., Si, F. H., Marafa, L. M. Indicator development for sustainable urban park management in Hong Kong. Urban Forestry \& Urban Greening 31 1-14 (2018)

20. Wen, C., Albert, C., Haaren, C. V. The elderly in green spaces: Exploring requirements and preferences concerning nature-based recreation. Journal of Sustainable Cities and Society 38 582593 (2018)

21. Winandari, M. I. R. Public open space for disaster mitigation in Tangerang housing estates. IOP Conf. Series: Earth and Environmental Science 106 012-021 (2018)

22. Abhijith, K. V., Kumar, P., Gallagher, J., McNabola, A., Baldauf, R., Pilla, F., Broderick, B., Sabatino, S. D., Pulvirenti, B. Air pollution abatement performances of green infrastructure in open road and built-up street canyon environmentsA review. Journal of Atmospheric Environment 162 71-86 (2017)

23. Selmi, W., Weber, C., Rivière, E., Blond, N., Mehdi, L., Nowak, D. Air pollution removal by trees in public green spaces in Strasbourg city, France. Journal of Urban Forestry \& Urban Greening 17 192-201 (2016)

24. Alcock, I., White, M., Cherrie, M., Wheeler, B., Taylor, J., McInnes, R., Kampe, E. O. I., Vardoulakis, S., Sarran, C., Soyiri, I., Fleming, L. Land cover and air pollution are associated with asthma hospitalisations : A cross-sectional study. Journal of Environment International 109 29-41 (2017)

25. Schuch, G., Neumann, S. S., Morgan, E., Choy, D. L. Water in the city : Open green spaces, land use planning and flood management - An Australian case study. Journal of Land Use Policy 63 539-550 (2017)

26. Galderisi, A. \& Treccozzi, E. Green strategies for flood resilient cities: The Benavento case study. Procedia Environmental Sciences 37 655-666 (2017)

27. Anguluri, R. \& Narayan, P. Role of green space in urban planning : Outlook towards smart cities.
Journal of Urban Forestry \& Urban Greening 2558 65 (2017)

28. Zhang, Y., Murray, A. T., Turner II, B. T. Optimizing green space locations to reduce daytime and nighttime urban heat island effects in Phoenix, Arizona. Landscape and Urban Planning 165162 171 (2017)

29. Hassan, A. M., \& Lee, H. The paradox of the sustainable city : Definitions and examples. Environmental Development and Sustainability, 17 (6), 1-19 (2014).

30. Bertram, C. \& Rehdanz, K. The role of urban green space for human well-being. Journal of Ecological Economics 120139 -152 (2015)

31. Lu, B. \& He, Y. 2017. Species classification using Unmanned Aerial Vehicle (UAV)-acquired high spatial resolution imagery in a heterogeneous grassland. ISPRS Journal of Photogrammetry and Remote Sensing 128 73-85 (2017)

32. Dash, J. P., Watt, M. S., Pearse, G. D., Heaphy, M., Dungey, H. S. Assessing very high resolution UAV imagery for monitoring forest health during a simulated disease outbreak. ISPRS Journal of Photogrammetry and Remote Sensing 131 1-14 (2017)

33. Tejada, P. J. Z., Varela, R. D., Angileri, V., Loudjani, P. 2014. Tree height quantification using very high resolution imagery acquired from an unmanned aerial vehicle (UAV) and automatic 3D photo-reconstruction methods. Europ. J. Agronomy 55 (2014) 89-99

34. Rusnák, M., Sládek, J., Kidová, A., Lehotský, M. Template for high-resolution river landscape mapping using UAV technology. Journal Measurement 115 139-151(2018)

35. Santesteban, L. G., Gennaro, S. F. D., Langreo, A. H., Miranda, C., Royo, J. B., Matese, A. Highresolution UAV-based thermal imaging to estimate the instantaneous and seasonal variability of plant water status within a vineyard. Agricultural Water Management 183 49-59 (2017)

36. Everitt, J. H., Yang, C., Fletcher, R. S., Drawe, D. L. Evaluation of High-Resolution Satellite Imagery for Assessing Rangeland Resources in South Texas. Rangeland Ecology \& Management. Volume 59, Issue 1, January, Pages 30-37 (2006)

37. Fisher, A., Danaher, T., Gill, T. Mapping trees in high resolution imagery across large areas using locally variable thresholds guided by medium resolution tree maps. International Journal of Applied Earth Observation and Geoinformation 58 86-96 (2017)

38. Pelta, R. \& Chudnovsky, A. A. Spatiotemporal estimation of air temperature patterns at the street level using high resolution satellite imagery. Science of the Total Environment 579675 -684 (2017)

39. Mukherjee, M. \& Takara, K. Urban green space as a countermeasure to increasing urban risk and the 
UGS-3CC resilience framework. International Journal of Disaster Risk Reduction 28 854-861 (2018) 